\title{
Pollutant Emissions from Boilers with Different Oil Nozzles
}

\author{
Dorota Anna Krawczyk* \\ Department of Heat Engineering, Faculty of Civil Engineering and Environmental Engineering, \\ Białystok University of Technology, Wiejska 45E, 15-351 Białystok, Poland
}

Received: 7 January 2015

Accepted: 22 March 2015

\begin{abstract}
Boilers working with light oil are popular in Polish heating systems and the amount of pollutants emitted during their work should be controlled. This paper shows the impact of nozzle parameters on pollutant emissions. The tests were conducted on a typical low-power burner used in houses and small public buildings. The pollution measurements were done for several oil nozzles fitting to a burner in the range of oil pressure from 0.8 to $1.5 \mathrm{MPa}$. The results show the high impact of oil pressure and nozzle type on the fuel combustion process and pollutant amounts, although the boiler's thermal capacity is constant. Carbon monoxide emissions for the oil pressure from 1.0 to $1.35 \mathrm{MPa}$ was low, although the average values in ranges of oil pressure from 0.8 to $1.0 \mathrm{MPa}$ and from1.35 to $1.5 \mathrm{MPa}$ for some nozzles was too high (330-2000 ppm).
\end{abstract}

Keywords: burner, pollutants, emission, oil pressure, boiler, injection angle

\section{Introduction}

New technologies have provided increased control of pollutant emissions from burners used in boilers operating for building heat, and have brought about significant improvement in appliance efficiency. Low $\mathrm{NO}_{\mathrm{X}}$ burners often are used for reducing NOx emissions. Hossaina et al. [1] presented the results of pollution reduction by a selective noncatalytic method in a pilot-scale diesel-fired tunnel furnace. As presented by Hukkanen et al. [2], a catalytic combustor can be used on a wood stove to achieve reduction of $21 \%$ for $\mathrm{CO}$ concentration. The results of tests made on engines fed with diesel oil have been shown by Ambrozik et al. [3] Some preliminary studies conducted in oil and gas boilers have been described by Krawczyk [4, 5]. The results of the measurements for coal have been presented, for instance, by Liszka and Ziebik [6], Liu et al. [7], and Li et al. [8].

In Poland coal, natural gas, propane-butane, and oil are used in households and public buildings. However, the choice of the fuel type depends on many factors, such as

*e-mail: d.krawczyk@pb.edu.pl local policy, economy, or technical capabilities. To achieve a lower level of air pollutants it is important to control and improve equipment used not only in heat centers or plants but also in small buildings. Some research conducted on the role of proper ratio of excess air in burners was described by Lugo-Leyte et al. [9]. Laryea and No [10] presented results of investigation for spray characteristics and cone angle. González-Espinosa et al. [11, 12] conducted experiments on the possibility of modifying diffuser geometry. Ghiaus et al. [13] showed that combustion efficiency depended on the position of the nozzles.

This paper presents the results of measurements conducted in a small thermal capacity power boiler room with a burner provided with different kinds of nozzles. The aim of the work was to define differences in pollutant emissions like NO and CO, depending on oil pressure and nozzle type.

\section{Methods and Experimental Object Description}

The experiments were carried out in northeastern Poland. The tested boiler had a nominal thermal capacity of 
Table 1. Fuel composition.

\begin{tabular}{|c|c|c|}
\hline Element & Unit & Value \\
\hline $\mathrm{C}$ & $\%$ & 84.28 \\
\hline $\mathrm{H}$ & $\%$ & 13.92 \\
\hline $\mathrm{S}$ & $\%$ & 0.52 \\
\hline $\mathrm{N}$ & $\%$ & 0.49 \\
\hline $\mathrm{O}$ & $\%$ & 0.79 \\
\hline
\end{tabular}

$18 \mathrm{~kW}$ and worked with an oil-forced draught burner. The efficiency of the boiler was $92 \%$. Table 1 presents the percentage compositions of elements in tested fuel. The calorific value of oil was $43.5 \mathrm{MJ} / \mathrm{kg}$, and its average kinematic viscosity was $3.6 \mathrm{~mm}^{2} / \mathrm{s}$. During all period of measurements the indoor temperature was $20^{\circ} \mathrm{C} \pm 0.5^{\circ} \mathrm{C}$. The measurements started after a minimum two-hour operation of the boilers each time. The inspection opening was made in the flue conduit to collect gas probes.

The measurements included flue gas temperature, ambient temperature, $\mathrm{O}_{2}, \mathrm{CO}_{2}, \mathrm{CO}, \mathrm{NO}_{\mathrm{X}}$, pressure, and an air excess number using the Manual Testo Flue Gas Analyzer. Instrument accuracy was as follows:

- Temperature between 0 and $+100^{\circ} \mathrm{C}\left( \pm 0.5^{\circ} \mathrm{C}\right.$ and $\pm 0.5 \%$ of measured value outside this range)

- Carbon monoxide concentration between +0 and +200 ppm CO $( \pm 10 \mathrm{ppm}$, in the range between +201 and 2000 ppm CO \pm 20 ppm)

- Efficiency between 0 and $+120 \%(0.1 \%)$

- Carbon dioxide concentration between +0 and $+10,000$ ppm $\mathrm{CO}_{2}: \pm 50 \mathrm{ppm}$

- Nitrogen monoxide between 0 and 100 ppm NO: \pm 5 ppm and between +101 and 2000 ppm NO: $\pm 0.5 \%$ of measured value

Test results were recorded in regular time intervals to check consistency in emission values, and each source, data transcription, and calculation was checked in respect to errors. Each time the measurements started with an oil pressure of $0.8 \mathrm{MPa}$. The concentrations of $\mathrm{CO}_{2}, \mathrm{O}_{2}, \mathrm{CO}$, $\mathrm{NO}$, and temperature of the flue gas were recorded every five minutes. One series included 20 measurements. Then the oil pressure was changed by $0.05 \mathrm{MPa}$ and all steps were repeated until oil pressure achieved 1.5 MPa. However, if $\mathrm{CO}$ emissions exceeded the maximum value of 2,000 ppm,the measurements were stopped - irrespective of oil pressure. During measurements I tested nozzles that differed by type: hollow (H), solid (S), partly solid (B) cone; spray angle (45-60o) and capacity (in range from 2.08 to $2.45 \mathrm{~kg} / \mathrm{h})$.

\section{Results and Discussion}

The first part of tests included three nozzles with hollow cones, which differed in capacity: $2.08 \mathrm{~kg} / \mathrm{h}$ (No. 1), 2.27 $\mathrm{kg} / \mathrm{h}$ (No. 2), and $2.45 \mathrm{~kg} / \mathrm{h}$ (No. 3). Data recorded during measurements showed the average pollution emission of the nozzle with biggest capacity was higher than from smaller ones (Fig. 1).

Carbon monoxide emission was the lowest in pressure range from 0.8 to $0.95 \mathrm{MPa}: 10-14 \mathrm{ppm} \mathrm{CO}$ from nozzle with capacity No. 1, 16-19 ppm from nozzle with capacity No. 2, and 22-78 ppm from nozzle with capacity No. 3 . In pressure range from 1.0 to $1.35 \mathrm{MPa}$, recorded values for all nozzles were comparable and acceptable (18-24 ppm). Finally, for pressure from 1.4 to $1.5 \mathrm{MPa}, \mathrm{CO}$ emission from nozzles with capacity Nos. 1 and 2 were still low (26$77 \mathrm{ppm}$ ), whereas for nozzle with capacity No. 3 emission level exceeded 2,000 ppm. Nitrogen monoxide emission (Fig. 2) was low for all nozzles (43-79 ppm).

The second part of the experiment included tests for four different nozzles regarding size and type, but with the same spray angle $\left(60^{\circ}\right)$ : Nos. I-IV. The results are presented in Figs. 3 and 4.

$\mathrm{CO}$ emissions from nozzle No. III at low pressure were low (16 ppm), but increased to 2,000 ppm while pressure was range between 1.3 and $1.5 \mathrm{MPa}$. For nozzle No. I the lowest values (average $19 \mathrm{ppm}$ ) were achieved for pressure range from 0.8 to $1.35 \mathrm{MPa}$, whereas for higher pressure the average $\mathrm{CO}$ emission was $45 \mathrm{ppm}$. A similar profile was obtained for nozzle No. II, but the values were, respectively, 24 and 57 ppm. Data from measurements of nozzle No.

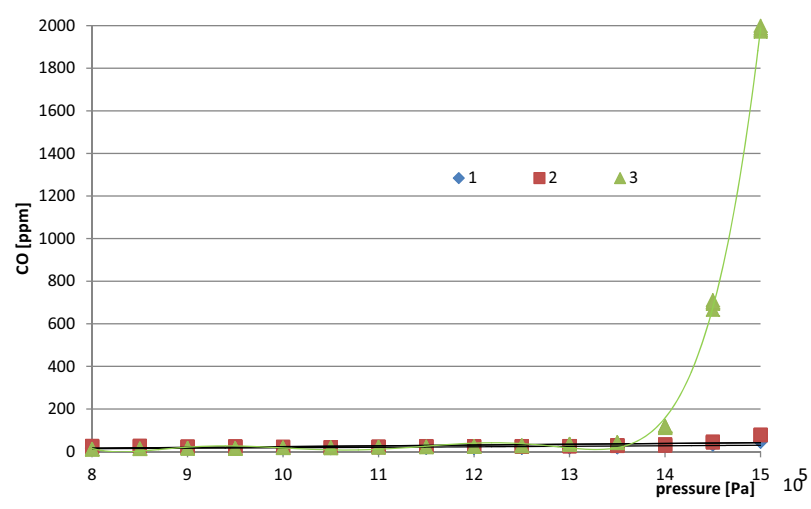

Fig. 1. CO emissions from nozzles with the same spray patterns.

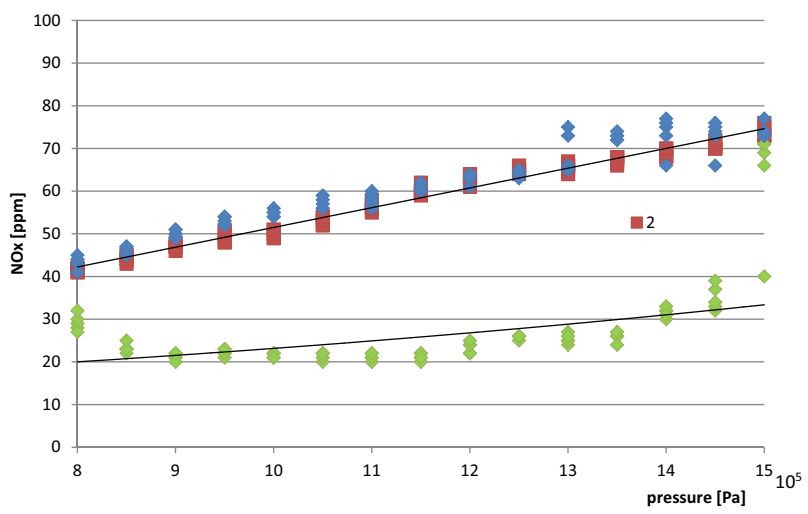

Fig. 2. NO emissions from nozzles with the same spray patterns. 


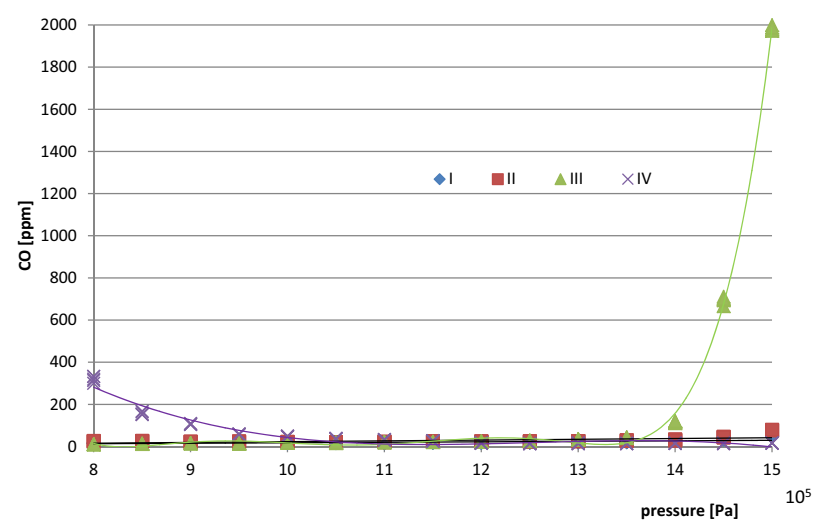

Fig. 3. $\mathrm{CO}$ emissions from nozzles with constant spray angle.

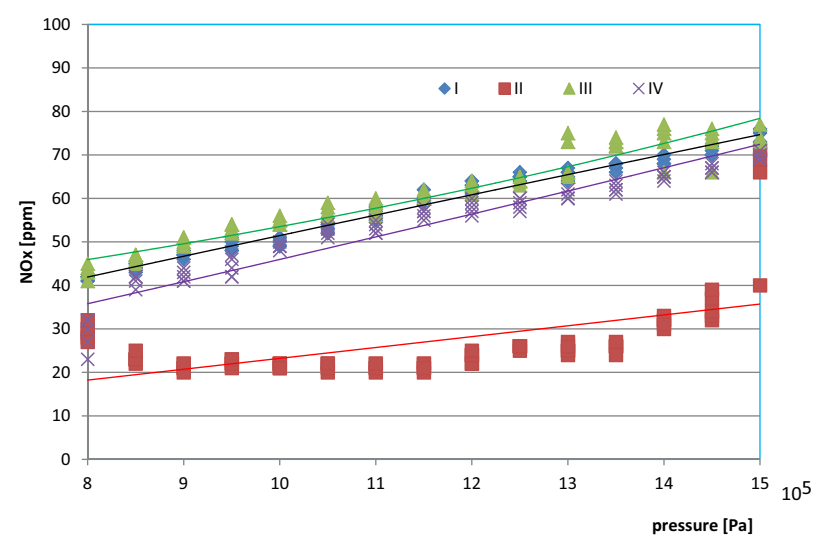

Fig. 4. NO emissions from nozzles with constant spray angle.

IV showed the reduction of $\mathrm{CO}$ levels with increasing oil pressure. The maximum value (330 ppm) was recorded for $0.8 \mathrm{MPa}$, while the minimum (15 ppm) was for $1.5 \mathrm{MPa}$. The results showed that only for pressure range from 1.1 to 1.2 MPa were $\mathrm{CO}$ values acceptable for all nozzles. The average NO emission (Fig. 4) in tested oil pressure range was from $22 \mathrm{ppm}$ (nozzle No. II) to 58-64 ppm (nozzle Nos. I, III, and IV).

The third part of measurements was conducted on three kinds of nozzles with different nozzle spray patterns (hol-



Fig. 5. CO emissions from nozzles with different spray patterns.

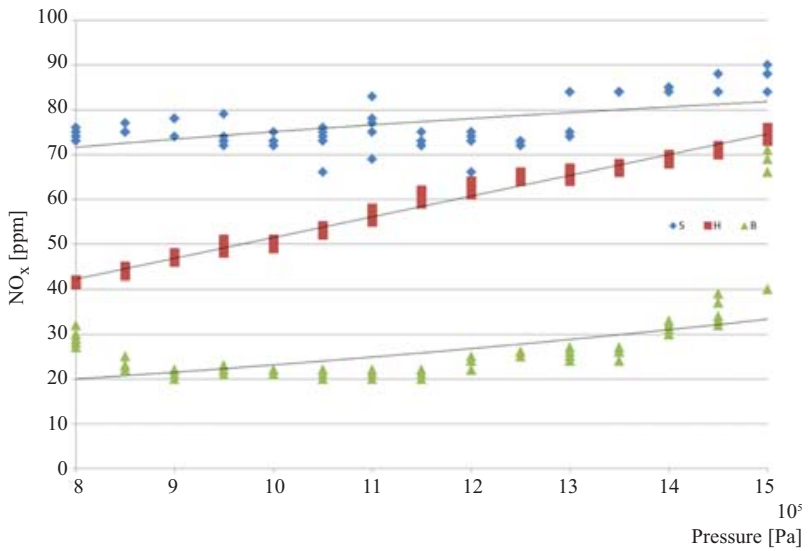

Fig. 6. NO emissions from nozzles with different spray patterns.

low cone - nozzle $\mathrm{H}$, solid cone - $\mathrm{S}$, and semi-solid coneB), while capacity rating was $2.67 \mathrm{~kg} / \mathrm{h}$ and spray angle was constant in all cases (Figs. 5, 6).

The main tendency observed from the results shows that the higher the oil pressure was, the higher the amount $\mathrm{CO}$ and NO recorded for all types of nozzles. The lowest $\mathrm{CO}$ concentrations were measured for hollow and semisolid nozzles (27-50 ppm in all pressure ranges). In the case of a hollow nozzle for low pressure (0.8-1.1 MPa), CO level was $18-27 \mathrm{ppm}$. For oil pressure $1.15 \mathrm{MPa}$ it started to rise (101 ppm) and exceeded 2,000 ppm CO for $1.3 \mathrm{MPa}$. NO level was below $90 \mathrm{ppm}$ for all nozzle types and oil pressure values. The lowest concentrations of nitrogen monoxide were recorded for semi-solid nozzles.

\section{Conclusion}

Measurements confirmed that pollutant emissions depend on oil pressure, but the correlation between $\mathrm{CO}$ concentration in the flue gas and oil pressure differed for solid and hollow nozzles. In the case of NO concentration, levels for all nozzles were low and increased with higher oil pressure. The choice of proper nozzle type and oil pressure level should be done by qualified staff because these factors determine pollutant levels. This is extremely important in the case of small single-family homes because their owners often forget about the necessity for technical inspections of boilers and burners.

\section{Acknowledgements}

This project was financed within the framework of science research S/WBIŚ/4/2014 funds at Bialystok University of Technology.

\section{References}

1. HOSSAINA K., JAAFARB M., MUSTAFAC A., APPALANIDUB K., ANI F. Application of selective noncatalytic reduction of $\mathrm{NO}_{\mathrm{X}}$ in small-scale combustion systems. Atmos. Environ. 38, 6823, 2004. 
2. HUKKANEN A., KAIVOSOJA T., SIPPULA O., NUUTINEN K., JOKINIEMI J., TISSARI J. Reduction of gaseous and particulate emissions from small-scale wood combustion with a catalytic combustor. Atmos. Environ., 50, 16, 2012.

3. AMBROZIK A., AMBROZIK T., KUCZYŃSKI D., ŁAGOWSKI P. The influence of Injection Advance Angle on Fuel Spray Parameters and Nitrogen Oxide Emissions for a Self-ignition Engine fed with Diesel Oil and fame. Pol. J. Environ. Stud. 23, (6), 1917, 2014.

4. KRAWCZYK D.A. The results of pollutants emission from boilers with light oil burners. Instal 7-8, 67, 2010 [In Polish].

5. KRAWCZYK D.A. Basic parameters influencing flue gases emission from boilers with light oil burners. Instal 6, 20, 2010 [In Polish].

6. LISZKA M, ZIEBIK A. Coal-fired oxy-fuel power unit e process and system analysis. Energy 35, 943, 2010.

7. LIU CH., LI Z., KONG W., ZHAO Y., CHEN Z. Bituminous coal combustion in a full-scale start-up ignition burner: Influence of the excess air ratio. Energy 35, 4102, 2010.

8. LI Z.Q., JING J.P., CHEN Z.C., REN .F, XU B., WEI H.D.
Combustion characteristics and $\mathrm{NO}_{\mathrm{X}}$ emissions of two kinds of swirl burners in a 300-MWe wall-fired pulverized-coal utility boiler. Combust. Sci. Technol. 180, 1370, 2008.

9. LUGO-LEYTE R., ZAMORA-MATA J.M., TOLEDOVELA'ZQUEZ M., SALAZAR-PEREYRA M., TORRESALDACO A. Methodology to determine the appropriate amount of excess air for the operation of a gas turbine in a wet environment. Energy 35, 550, 2010.

10. LARYEA G.N., NO S.Y. Spray angle and breakup length of charge-injected electrostatic pressure-swirl nozzle. Journal of Electrostrostatic 60, 37, 2004.

11. GONZÁLEZ-ESPINOSA A., LOZANO A., GARCÍA J.A., BARRERAS F., LINCHE E. Design modification of the air diffuser in the burners of a fuel oil power plant. Part II: Interaction with the liquid spray. Fuel 124, 141, 2014.

12. GONZÁLEZ-ESPINOSA A., LOZANO A., GARCÍA J.A., BARRERAS F., LINCHETA E. Design modification of the air diffuser in the burners of a fuel oil power plant. Fuel, 111, 280, 2013.

13. GHIAUS C., BELARBI R., ALLARD F. Optimal settings of residential oil burners. Energ. Buildings 34, 83, 2002. 